\title{
"RESETTLED REFUGEES FROM ETHIOPIA: WHO GETS INTO THE UNITED STATES?"
}

\author{
Peter Koehn, University of Montana
}

\section{Introduction}

Success in flight from one's country of origin does not guarantee a secure place of refuge. Most refugees languish for years, even decades, in a neighboring country of first asylum. In general terms, relocation in the industrialized North depends upon individual initiative and application of receiving-country admission policy. This article identifies main waves of post-revolution refugees from Ethiopia who have managed to secure resettlement in the US and investigates characteristics which distinguish the admitted from their counterparts who have not moved beyond first refuge in Sudan.

\section{The First Step}

Experiences of Ethiopians and Eritreans in Sudan reveal much about the initial and subsequent steps in the refugee-migration process. The trip to Sudan typically is harsh and risky. Most migrants walk the entire way. Refugees from Ethiopia's urban areas usually must travel longer distances to reach protection in Sudan in comparison with rural residents. $\{1\}$ In some cases, families must sell their property, including their homes, in order to pay fees charged by guides to lead a son or daughter through inhospitable terrain. Although they faced no threat that Sudanese government authorities would turn them back, nearly 15 percent of the respondents in Mekuria Bulcha's survey (2) reported suffering armed attack, robbery, or another form of violence during flight. About $\mathbf{4 0}$ percent of this group of refugees lacked food and water for some part of the trip, and 12 percent contracted malaria or another disease. $\{3\}$

Rural refugees generally settle at the first point of safety within the receiving country. Spontaneous border settlements have existed since the outbreak of fighting in the Eritrean liberation struggle.(4) While the flight of rural refugees tends to be a single-step phenomenon, most urban exiles engage in multiple-step migration. [5] Migrants from urban centers usually continue their journey further into Sudan.(6) The educated often end up in Khartoum. (7) The prevailing reasons refugees give for moving on to Khartoum are the search for employment and for third-country resettlement. $\{8\}$

\section{First Asylum in Sudan}

In light of the fact that many refugees from Ethiopia have relied upon Sudan as a place of first asylum, it is important to understand the conditions that political migrants face there. The majority of refugees live in rural areas; less than half reside in one of Sudan's cities. In 1984, about 80 percent of the

$$
\begin{aligned}
& \text { In light of the fact that many } \\
& \text { refugees from Ethiopia have } \\
& \text { relied upon Sudan as a place } \\
& \text { of first asylum, it is } \\
& \text { important to understand the } \\
& \text { conditions that political } \\
& \text { migrants face there. }
\end{aligned}
$$

refugees from Ethiopia lived in spontaneous residential circumstances; that is, they were "self-settled and lived scattered among the local population." $\{9\}$ The remaining 22 percent inhabited 23 organized settlements in eastern and central Sudan operated since 1980 by the Sudanese government with international assistance. There are two major categories of organized settlement. In the land settlements, refugee families are awarded small plots of land and are expected to subsist through food-crop cultivation, animal husbandry, and occasional wage labor.\{10] In the wageearning settlements located in close proximity to large-scale commercial farms or government agricultural schemes, political migrants survive by providing unskilled labor.\{11\} Many Eritreans, in particular, encounter continued agitation from political activists who pressure them to serve as a rear support group for the guerrilla forces.\{12\} At the same time, exile political organizations perform an important role by operating their own assistance and educational programs, in mobilizing refugees and preserving their sense of identity, in informing newcomers about employment and educational opportunities, and in mediating on their behalf when they must interact with domestic and international agencies.(13)

Upon arrival in Sudan, the refugee must adapt to a different language and culture and meet the challenge of basic survival. Shelter and subsistence top the list of initial problems reported by respondents in six settlement sites. $\{14\}$ Lack of free health care adversely affects refugees living outside of organized settlements. In two rural spontaneous sites studied by Mekuria Bulcha, 30 percent of the children in the sampled refugee households died within the first year and 20 percent of all family members perished within the space of four years. \{15\} Laws restricting refugee movement within Sudan and the acquisition of work permits and licences present additional barriers to economic adjustment.\{16\} Finally, many are burdened by the pain of separation from close family and isolation from the homeland community that previously provided one's sense of belonging and identity. $\{17\}$ 
After five years in the Sudan, the vast majority of refugees from Ethiopia interviewed by Mekuria Bulcha had not resolved all of the initial problems they encountered. In fact, over 20 percent of those who settled spontaneously in a Sudanese village or town had solved few or none of their problems. [18\}

Most refugees from Ethiopia find it difficult to subsist in rural Sudan. Mekuria Bulcha's 1982 interviews revealed that, "above two-thirds of the respondents were unable to achieve economic self-reliance and were therefore on the brink of starvation." [19] Families led by women are the most vulnerable since the rate of unemployment is much higher among female than male household heads. $\{20\}$ Underemployment rates are high for all refugees in the labor market. Most household heads rely upon seasonal agricultural employment for five to six months in good years. Wages are low and various forms of exploitation are widespread.\{21\} Only 40 percent of all households retained any income after meeting food and shelter expenses alone.\{22\} Most refugee families, moreover, cannot count on breaking out of economic dependency and destitution over time. According to Mekuria, "the incidence of material poverty was as frequent among those who had been in the Sudan between 4 and 8 years as those who had been there just a year or two." $\{23\}$

Khartoum's refugees face problems comparable to those experienced by their compatriots living in eastern Sudan. At least 20 percent of the refugees from Ethiopia living in urban areas were unemployed in 1984, and a higher proportion struggled to subsist through underemployment in low-paying work. $\{24\}$ In one large-scale survey, "over two-thirds of the sample reported that they received less daily income than is required to provide food, shelter, and basic necessities." $\{25\}$ One survival response is to occupy shared-living quarters with up to 12 people.(26)

Skilled urban refugees, often lacking documents authorizing residence in Khartoum, are subject to exploitation at the hands of Sudanese landlords and employers as well as to arrest and involuntary relocation. (27) Refugees are routinely refused credit, barred by law from owning fixed assets, and blamed for Khartoum's economic problems.\{28\} Marginally integrated into the receiving society and economy, many seek "an external solution to their survival problems." $\{29\}$ Meanwhile, the Sudanese government provides no assistance to urban refugees and they are virtually ignored by international donor agencies. $\{30\}$

The focus on refugee migration to Sudan yields important insights. First, most Eritreans and Ethiopians who sought protection there have experienced a decline in their standard of living. Nearly everyone left all of their possessions behind. Unemployment and underemployment is much higher in the new location than prior to flight. In short, "flight entails instant impoverishment" - even for those who were wealthy in the country of origin.\{31\}

Many refugees resort to agricultural wage labor in the countryside, and to petty trade, domestic work, and various informal-sector economic activities in towns and urban centers. $\{33\}$ Availability of low-paying employment opportunities continues to shrink in the face of drought and increasing numbers of refugees and Sudanese migrant laborers in the rural areas along with competition from "unskilled but Arabicspeaking and documented Sudanese" in the cities.\{34\} The end result, then, has been little progress toward self-reliance among many of the refugees who live in Sudan. $\{35\}$ This is consistent with the African refugee experience described in 1982 by Art Hansen:

[F]or almost everyone the process of becoming a refugee is a transition from relative security and prosperity to uncertainty and poverty. Some starve; many become undernourished. Illness, exhaustion, and accident accompany many on their journey and await others after the rigors of the trip. Political sponsorship is abandoned in that the refugee rejects the protection of the only government under which he or she has the rights of a citizen or resident. Material wealth is lost or abandoned, and the refugee is also stripped of an important means to generate more wealth - the access to resources that is an aspect of the political and social relationships that are abandoned or destroyed.(36)

\section{U.S. Resettlement}

The population transfer from Ethiopia to the United States has involved a small proportion of the total refugee population. The U.S. Immigration and Naturalization Service allowed some Ethiopians and Eritreans to enter the country as seventhpreference (refugee) immigrants by the late 1970s. [37] Many others joined the initial wave immediately following enactment of the Refugee Act in 1980. The larger second post-revolution wave of official refugees from Ethiopia covers the peak years from 1982 to 1984 through the present. Between 1982 and 1987, 12,551 resettled refugees from Ethiopia arrived in the United States. (38) Annual admissions have declined substantially in recent years, however. This is primarily because INS circuit riders in Sudan have virtually exclusively approved applicants with family ties in the U.S. - a criterion which few Africans can meet. $\{39\}$

In order to learn more about the backgrounds of those granted admission, the author coded available information related to household heads and independent applicants admitted with official-refugee status from a 10 percent sample of the bio-data forms received by 1984 at the Refugee Data Center inNew York City ("RDC Bio-data sample"). These forms are numbered sequentially, and are arranged by date of entry in the U.S. and by country (or area) of application for resettlement. The procedure for this study involved a systematic sample with a random start from the 12 file boxes of applicants from Sudan, 2 of Djibouti applicants, and one each for refugees from Somalia, Kenya, Egypt, and via Europe. The results from the Refugee Data Center Bio-data sample of refugee household heads who reached the U.S. by 1984 allow for selected comparisons between the first and early second waves admitted from Ethiopia.\{40\} The next sections compare 
the two waves by nationality, occupation, education, and family ties. Natlonality

Table 1 indicates that refugee household heads identified as Amhara constitute a plurality ( 36 percent) of the first wave. The rest of this arrival group is roughly evenly split among Eritreans, Tigreans, Oromo, and the combined category of other ethnic groups. Eritreans clearly predominate within the second wave, however. Among those who arrived between 1982 and 1984, 44 percent are Eritrean. During this interval, only 26 percent of the entering refugee household heads are Amhara.[41] The representation of Tigrean refugees remains constant during both waves, but the proportion of Oromo and "others" declines dramatically over time.

\section{Home-Country Occupation}

Table 2 shows that there is no substantial decline among household heads from Ethiopia arriving during the second wave in the proportion from high-status occupational backgrounds and no significant increase in the percentage who were farmers and laborers. [42] The only major changes are the increase in former students entering as official refugees after 1981 and the decrease in homemakers and the unemployed from the first to the second wave.

\section{Educatlonal Attainments}

Table 3 displays the educational attainments of the sampled refugees by wave. A higher proportion of secondwave than first-wave refugee household heads from Ethiopia had at most completed a primary education (26 percent versus 17 percent). On the other hand, there are more universityeducated persons in the second wave than in the first group ( 9 percent to 3 percent). There are noteworthy variations in these results by ethnicity. The educational levels attained by admitted Eritreans decline considerably from the first to the second wave. To a lesser extent, this pattern also prevails among the Amhara in the sample. Among the Oromo and "other" groups, however, educational attainments

TABLE 1

Ethnicity of Refugee Household Heads from Ethlopla By U.S. Arrival Wave

\begin{tabular}{lccccc} 
& \multicolumn{5}{c}{ ETHNICITY } \\
Arrival Wave & Eritrean & Amhara & Tigray & Oromo & Other \\
$\% 1981$ or before $(\mathrm{N}=166)$ & $16.9 \%$ & $35.5 \%$ & $16.9 \%$ & $12.7 \%$ & $18.1 \%$ \\
$\% 1982-1984(\mathrm{~N}=339)$ & 43.7 & 25.7 & 18.6 & 5.0 & 7.1 \\
Source: R.D.C. Bio-data sample. &
\end{tabular}

TABLE 2

Home Country Occupational Background of Refugee Household Heads from Ethlopia By Wave

\begin{tabular}{lcc}
\multicolumn{1}{c}{$\begin{array}{c}\text { Principal } \\
\text { Home-Country Occupation }\end{array}$} & $\begin{array}{c}\text { A'81 or prior } \\
\text { (N=175) }\end{array}$ & $\begin{array}{c}\text { \%'82-'84 } \\
\text { (N=375) }\end{array}$ \\
Professional, top policy maker & $1.7 \%$ & $1.7 \%$ \\
Owner, mgr large business & 3.4 & 0.8 \\
Public servant, teacher, medical worker & 23.4 & 20.8 \\
Trader, owner small business & 7.4 & 7.2 \\
Skilled worker & 6.3 & 4.8 \\
Secretarial & 12.0 & 12.4 \\
Farmer, worker & 18.3 & 20.3 \\
Student only & 13.1 & 26.9 \\
Unemployed, homemaker & 14.3 & 5.3
\end{tabular}

Source: R.D.C. Bio-data sample

Educational Attainments of Refugee Household Heads from Ethiopla By Wave

\section{Arrival Wave}

1981

$\begin{array}{clllll}\text { or earlier }(\mathrm{N}=181) & 16.6 \% & 26.5 \% & 33.7 \% & 19.9 \% & 3.3 \% \\ 1982-1984(\mathrm{~N}=381) & 26.2 & 24.7 & 22.3 & 17.6 & 9.2\end{array}$


actually increase from the first to the second wave.

\section{Family Tles}

Exactly the same percentage of firstand second-wave principal applicants admitted from Ethiopia (14 percent) reported that they knew of a close relative who resided in the U.S. at the time of application for resettlement. These low percentages suggest that family reunification is not an important factor among the second-wave refugee household heads from Ethiopia who settled in the US during the first decade following the revolution. Since 1984, however, the admission of official refugees under the U.S. resettlement programincreasingly has been restricted to persons who can demonstrate the presence of caring family members who already are legally settled in the receiving country. (43)

\section{Who Gets in?}

Only a small proportion of the total number of refugees from Ethiopia are ever accepted for resettlement in the North. How do the individual household heads selected for placement in the U.S.A. resemble and/or differ from their compatriots who remain in neighboring countries of temporary asylum? Although the answer to this important question promises to enhance our understanding of the step-migration process, detailed comparative data along these lines have not been available in the past. The following discussion provides a focused comparison of U.S.-resettled and non-resettled refugees from Ethiopia who first received protection in Sudan.

\section{Sudan Focus}

Most Eritrean refugees and non Somali-speaking Ethiopians have fled to Sudan. In 1990, Sudan accommodated roughly 660,000 refugees from Ethiopia - mainly Eritreans and Tigreans. Some have lived in Sudan for over 20 years. (44)

Information on the refugees who remain in Sudan is drawn from two sources of local field work: Jerry Weaver's 1984 survey of urban refugees from Ethiopia living in the Khartoum area and Mekuria Bulcha's 1982-1983 eastern Sudan sample taken from three
TABLE 4

Selected Characteristics of Refugees from Ethiopia Still Living in Sudan and Resettled In the U.S. by 1984

$\begin{array}{lccc}\text { KhaRACTERISTICS } & \begin{array}{c}c \\ \text { Khartoum } \\ \text { Study } \\ (\mathrm{N}=1012)\end{array} & \begin{array}{c}\text { E.Sudan } \\ \text { Study } \\ (\mathrm{N}=413)\end{array} & \begin{array}{c}\text { U.S. } \\ \text { R.D.C. } \\ \text { Bio-data } \\ (\mathrm{N}=359)\end{array} \\ \begin{array}{lccc}\text { Gender } \\ \text { Male }\end{array} & 90.0 \% & 84.7 \% & 88.9 \% \\ \text { Female } & 10.0^{\mathrm{a}} & 15.3 & 11.1 \\ \text { Age } & & & \\ 21 \text { or less } & 21.7 & 15.3^{\mathrm{b}} & 8.9 \\ 22-25 & 26.8 & 44.4^{\mathrm{b}} & 26.3 \\ 26-30 & 24.7 & -- & 34.4 \\ 31 \text { and older } & 27.3 & 40.3 & 30.4\end{array}$

Year Arrived In Sudan

$\begin{array}{llcr}\text { Prior to } 1976 & \text { C } & 10.6 & 0.0 \\ 1976-1979 & \text { C } & 59.6 & 18.7 \\ 1980-1982 & \text { C } & 29.8 & 63.9 \\ 1983-1984 & \text { C } & -- & 17.4\end{array}$

Ethnic Identification

$\begin{array}{lrcr}\text { Eritrean } & 67.1 & 59.0^{\circ} & 42.2 \\ \text { Tigrean } & 15.6 & -.- & 22.9 \\ \text { Amhara } & 14.5 & 25.0 & 31.0 \\ \text { Oromo } & 1.4 & 16.0 & 2.8 \\ \text { Other } & 4.0 & -- & 1.1\end{array}$

Religlous Identification

Ethiopian Orthodox

Other Christian

82.5

79.8

Muslim

16.4

12.9

7.3

\section{Educational Attainment}

Completed University

Some post-secondary

Completed secondary or equiv. 12.4

$\begin{array}{rcr}1.3 & 2.7 & 1.7 \\ 3.5 & -- & 16.2 \\ 12.4 & 7.5 & 24.9 \\ 32.1 & -- & 27.9 \\ 21.0 & 15.0 & 7.5 \\ -- & -- & 15.9 \\ 29.2 & 74.8 & 5.9\end{array}$

Some post primary

Completed primary

Some primary

No formal

80.0

20.0

aHousehold heads only.

b20 or less; 21-30.

"No information available.

${ }^{d}$ Reported only by language spoken.

Source: Weaver, "Sojourners," 149; Mekuria Bulcha, Flight, pp. 98, 150, 153-154; R.D.C. Bio-data sample. 
organized settlement sites and five spontaneous settlement areas in urban, semi-urban, and rural settings. $\{45\}$. Table 4 presents data on six background characteristics across the three subsets of refugees from Ethiopia who fled to Sudan.(46)

\section{Gender, Age, Vintage, Ethniclty, and Religlon}

Gender and age prove not to be particularly interesting variables, although the household heads admitted to the U.S. are somewhat more likely to be in their twenties and less likely to be younger. Striking is the much greater tendency for later migrants to secure resettlement and for the earliest refugees to remain in Sudan. Table 4 also shows that Amhara and Christians who fled to Sudan have succeeded within the U.S. resettlement program in numbers that are disproportionate to their presence in the total pool of refugees from Ethiopia who currently live in Sudan. Eritreans and Muslims in Sudan have been particularly disadvantaged in obtaining third-country resettlement in the United States.

\section{Education}

Table 4 suggests that educational background exerts the greatest influence over prospects of entry to the US. While less than 5 percent of political migrants living in Sudan had attended a university, nearly 20 percent of resettled household heads had attained this

$$
\begin{aligned}
& \text {...the findings reviewed here } \\
& \text { point to educational and } \\
& \text { occupational background } \\
& \text { factors as particularly } \\
& \text { influential considerations } \\
& \text { affecting the third-country } \\
& \text { resettlement stage of the } \\
& \text { refugee step-migration } \\
& \text { process. }
\end{aligned}
$$

educational level. Less than 30 percent of the resettled sample had a primary education or less; half of the Khartoum sample and 90 percent of the eastern

TABLE 5

Homeland Occupational Background of Refugees from Ethlopla Still Llving in Sudan and Resettled In the U.S. by 1984

\begin{tabular}{lccc} 
& \multicolumn{2}{c}{ SUDAN } & U.S. \\
Khartoum & $\begin{array}{c}\text { Study } \\
\text { E.Sudan }\end{array}$ & $\begin{array}{c}\text { R.D.C. } \\
\text { Study } \\
\text { Bio-data }\end{array}$ \\
Subsistence farmer/herder & $7.0 \%$ & $23.0 \%$ & $5.5 \%$ \\
Homemaker & 18.9 & 18.9 & 2.0 \\
Student only & 29.2 & 4.1 & 22.0 \\
Domestic helper & 1.3 & 6.1 & 2.3 \\
Unskilled laborer & $9.1^{2}$ & 11.7 & 16.8 \\
Trader, artisan & $3.6^{\circ}$ & 8.0 & 5.8 \\
Skilled labor & 11.1 & 0.7 & 2.6 \\
Clerk, secretary & $2.0^{\circ}$ & - & 9.3 \\
Teacher, clergy & 0.0 & - & 11.1 \\
Soldier, police & 3.4 & 9.2 & 4.1 \\
Public servant & 0.0 & - & 10.7 \\
Professional, manager & 6.7 & - & 4.0 \\
Other & 0.0 & 8.3 & 0.3 \\
Unemployed & 6.8 & 9.9 & 4.1
\end{tabular}

a"Service." b"Self-employed." c"Office."

Source: Weaver, "Sojourners," 152; Mekuria, Bulcha, Flight, p. 155; R.D.C. Bio-data sample.

Sudan group possesssuch limited formal educational attainments.

\section{Occupation}

Occupational background also relates to entry under the U.S. resettlement program. Table 5 indicates that nearly 40 percent of admitted household heads had worked as a teacher, professional, manager, administrator, secretary, or soldier in Ethiopia. Since only about 10 percent of those who remained in Sudan reported such occupational backgrounds, we can safely conclude that applicants with these particular work experiences in the sending country have a better chance of third-country resettlement. Former subsistence farmers and herders, on the other hand, are the least likely to move beyond rural settlements in border regions and are the most underrepresented component of the homecountry labor force in the resettled sample. The data also suggest that most of the former skilled workers managed to gravitate to the capital of the initial receiving country. Although relatively few of the skilled laborers have been selected for admission to the US, many have moved on to jobs in the Middle East.(47)

\section{Conclusion}

While only suggestive, the findings reviewed here point to educational and occupational background factors as particularly influential considerations affecting the third-country resettlement stage of the refugee step-migration process. Although not required to do so by legislation dealing with refugee resettlement, U.S. administrative gatekeepers in Sudan have given preference in the screening process to applicants with educational and occupational backgrounds deemed most conducive to adaptation in the receiving society. $\{48\}$ 


\section{NOTES}

1. Mekuria Bulcha, Flight and Integration: Causes of Mass Exodus from Ethiopia and Problems of Integration in the Sudan (Uppsala: Scandinavian Institute of African Studies, 1988), pp. 135-136; Lucia A. McSpadden, "Ethiopian Refugee Resettlement in the Western United States: Social Context and Psychological Well-Being," International Migration Reoiew 21, No. 3 (1987):804.

2. Mekuria Bulcha, Flight, pp. 106, 132.

3. Partly as a consequence of their demanding and exhausting flight, many refugees proved susceptible to health problems upon arrival in Sudan. Mekuria Bulcha, Flight, pp. 139-141. On the experiences of Somali refugees, who tended to flee in small groups, see Sidney R. Waldron, "Somali Refugee Background Characteristics: Preliminary Results from the Qoriooley Camps" (mimeo, 1983), p. 7.

4. Leon Gordenker, Refugees in International Politics (New York: Columbia University Press, 1987), p. 147.

5. Mekuria Bulcha, Flight, pp. 137-138.

6. Of course, some rural migrants also make their way to the larger towns in Sudan. See Ahmed Karadawi, "The Problem of Urban Refugees in Sudan," in Refugees: A Third World Dilemma, edited by John R. Rogge (Totowa: Rowman and Littlefield, 1987), pp. 116, 119-120.

7. Mekuria Bulcha, Flight, pp. 136-138. Nearly half of the respondents in Eyob Goitom's survey of 320 Khartoum refugees originated in Asmara. Eyob Goitom, "Systems of Social Interaction of Refugee Adjustment Processes: The Case of Eritrean Refugees in Khartoum, Sudan," in Refugees: A Third World Deliemma, edited by John R. Rogge (Totowa: Rowman and Littlefield, 1987) p. 137.

8. In discussing the results of one local study, Jerry Weaver refers specifically to resettlement in the United States. Jerry L. Weaver, "Sojourners Along the Nile: Ethiopian Refugees in Khartoum," in Journal of Modern African Studies 23, No. 1 (1985):150-151. An earlier research project (cited in Mekuria Bulcha, Flight, p. 138) found considerable interest in migration to Europe and the Middle East as well as to the United States. Also see Karadawi, “Urban Refugees," pp. 121122; Eyob Goitom, "Eritrean Refugees," p. 137.

9. Mekuria Bulcha, Flight, p. 30.

10. The Somali government introduced incomegenerating programs and pilot agricultural schemes for a small section of its refugee-camp population in 1982. Hanne Christensen, "Spontaneous Development Efforts by Rural Refugees in Somalia and Pakistan," in Refugees: $A$ Third World Dilemma, edited by John R. Rogge (Totowa: Rowman and Littlefield, 1987), p. 200.

11. Mekuria Bulcha, Flight, p. 30; Hiram Ruiz, Beyond the Headlines: Refugees in the Horn of Africa (Washington, D.C.: U.S. Committee for Refugees, 1988), p. 32. This applies to settlements in and around Gedaref, for instance. Karadawi, "Urban Refugees," p. 118.

12. Mekuria Bulcha, Flight, pp. 82-83; Eyob Goitom, "Eritrean Refugees," p. 140.
13. Karadawi, “Urban Refugees," pp. 121-122; Eyob Goitom, "Eritrean Refugees," p. 141.

14. Mekuria Bulcha, Flight, p. 140.

15. Over half of the interviewees who complained of poor personal health had contracted their affliction after arrival in Sudan. Mekuria Bulcha, Flight, pp. 141, 171.

16. Mekuria Bulcha, Flight, p. 142.

17. Mekuria Bulcha, Flight, pp. 198-199.

18. Mekuria Bulcha, Flight, pp. 142-143.

19. Mekuria Bulcha, Flight, pp. 162-163.

20. Mekuria Bulcha, Flight, p. 164 . On the barriers to employment of women outside of service and domestic jobs in Khartoum, see Weaver, "Sojourners," 152-153; Eyob Goitom, "Eritrean Refugees," p. 138.

21. Mekuria Bulcha, Flight, pp. 172-173.

22. Moreover, they "still were not free from malnutrition." Mekuria Bulcha, Flight, pp. 155, 170.

23. Mekuria Bulcha, Flight, p. 163.

24. Weaver, "Sojourners," 153; Eyob Goitom, "Eritrean Refugees," pp. 139-140.

25. Weaver, "Sojourners," 153.

26. Eyob Goitom, "Eritrean Refugees," p. 139.

27. Weaver, "Sojourners," 153-155; Gordenker, Refugees, p. 148; Al Santoli, New Americans: Immigrants and Refugees in the U.S. Today (New York: Viking, 1988), p. 95.

28. Weaver, "Sojourners," 154-155. Specifically, they are blamed for the shortage of housing and rising rents, pressures on public services, and insufficient supplies of consumer goods. Karadawi, "Urban Refugees," pp. 124, 116; Santoli, New Americans, p. 96; Eyob Goitom, "Eritrean Refugees," p. 139.

29. Weaver, Flight, p. 148.

30. Weaver, "Sojourners," 147; Karadawi, "Urban Refugees," p. 126.

31. Mekuria Bulcha, Flight, p. 200.

32. Furthermore, 67 percent had owned productive assets in Ethiopia, whereas only 12 percent possessed such property in Sudan. Mekuria Bulcha, Flight, p. 171.

33. Mekuria Bulcha, Flight, pp. 155-158; Weaver, "Sojourners," 152.

34. Weaver, "Sojourners," 153; Mekuria Bulcha, Flight, p. 158.

35. Mekuria Bulcha, Flight, p. 200.

36. Art Hansen, "Self-Settled Rural Refugees in Africa: The Case of Angolans in Zambian Villages," in Involuntary Migration and Resettlement: The Problems and Responses of Dislocated People, edited by Art Hansen and Anthony Oliver-Smith (Boulder: Westview Press, 1982), p. 32.

37. The Immigration and Nationality Act of 1965 allowed the "conditional" entry of 6 percent of the total annual immigration quota (i.e., about 17,000 principal applicants and 25,000 persons) under a seventh-preference category established for those who had fled communist-dominated countries, or a Middle Eastern country. John A. Scanlan, "First Final Research Report Submitted to the
Select Commission on Immigration and Refugee Policy," in U.S. Immigration Policy and the National Interest, Appendix $\mathrm{C}$ to the Staff Report (Washington, D.C.: The Commission, 1980), PP. 105-106.

38. United States, Immigration and Naturalization Service, Statistical Yearbook of the Immigration and Naturalization Seroice, 1987 (Washington, D.C.: U.S. Government Printing Office, 1988), p. 50.

39. Beverly G. Hawk, " $\Lambda$ fricans and the 1965 U.S. Immigration Law" (Ph. D. dissertation, University of Wisconsin-Madison, 1988), pp. 112 114, 161, 287.

40. The actual date of arrival usually is not recorded in the bio-data files. In its place, we relied upon the year in which an applicant received approval to enter the U.S. since this corresponds in most cases with the year of arrival. At the time of research, nearly 70 percent of the total sample (84 percent of the Eritreans) had arrived in the U.S. during the second wave (i.e., after 1981).

41. These data do not support Beverly Hawk's assertion ("Africans," p. 126) that most resettled refugees from Ethiopia are Amhara.

42. The available FY 1987 data continue to support this conclusion. See U.S., INS, 1987 Yearbook, p. 40. 43. See Donald J. Cichon, Elzbieta M. Gozdziak, and Jane G. Grover, The Economic and Social Adjustment of Non-Southeast Asian Refugees, Vol. I (Falls Church: Research Management Corporation, 1986), p. 29.

44. Tessa Williams, "Sudan: Twenty Years on," Refugees 72 (February 1990):31.

45. See Weaver, "Sojourners," 147-150; Mekuria Bulcha, Flight, pp. 92-97. Most refugees from Ethiopia live in eastern Sudan. An estimated 200,000 inhabit Sudan's largest cities of Khartoum, Gedaref, Kassala, and Port Sudan. Williams, "Twenty Years," 31. Mekuria Bulcha's research included the town of Gedaref.

46. The R.D.C. sample consists of principal applicants for refugee status - almost all of whom are heads of household or independent individuals. About 35 percent of the Khartoum group are the spouses of male household heads who were away at work at the time the survey took place. Weaver, "Sojourners," 150. Mekuria Bulcha's team also interviewed some wives in place of absent male household heads. He found it necessary to make such substitutions in nearly 20 percent of the sampled households in two of the three organized settlements. Mekuria Bulcha, Flight, p. 95.

47. Also see Mekuria Bulcha, Flight, p. 138; Eyob Goitom, "Eritrean Refugees," pp. 138-140.

48. It also is conceivable that the narrow definition of "refugee" which guides U.S. admission practice amounts to a formidable class barrier to further migration. However, overseas gatekeepers generally have not enforced a particularly narrow definition in the refugee-resettlement process. See Peter H. Koehn, Refugees from Reoolution: U.S. Policy and Third World Migration (Boulder: Westview Press, forthcoming). 